\title{
Cooperative Learning Approach as Innovation to Improve Students' Academic Achievement and Attitude in Teaching Biology
}

\author{
Resty C. Samosa iD \\ Graceville National High School, Department of Education, City Schools Division of San Jose del Monte Bulacan, Philippines \\ $\triangle$ Corresponding Author: Resty C. Samosa, E-mail: resty.samosa002@deped.gov.ph
}

ARTICLE INFORMATION ABSTRACT

Received: December 18, 2020

Accepted: January 14, 2021

Volume: 3

Issue: 1

DOI: $10.32996 /$ jweep.2021.3.1.1

\section{KEYWORDS}

Academic achievement, attitudes

Biology, cooperative learning

approach
The quality of education that teachers provide to student is highly dependent upon what teachers do in the classroom. Thus, in preparing the students of today to become successful individuals of tomorrow, science teachers need to ensure that their teaching is effective. This study aimed to compares the application of Cooperative learning approach on the students' academic achievement and attitudes in teaching biology. The study sought to determine the effectiveness of cooperative learning approach against conventional teaching. The study employed the experimental type of research. The design compared the result obtained from researcher - made achievement test and attitude survey in biology in experimental sample which is cooperative learning approach with the control sample exposed to Direct Instruction. The study revealed that the gained scores of the experimental group gained $41.86 \%$ from the pre- and post-achievement test greater than the controlled group gained score of $36.49 \%$. Furthermore, in the attitude survey showed that the experimental group gained $81.90 \%$ from the pre- and post-attitude survey which greater than the control group gained $81.69 \%$. Using t- test of significance in both control group and experimental group showed that there is no significance difference between pre achievement test and post - achievement test at probability level of greater than 0.05 . In $\mathrm{F}$-test revealed that there is no significant difference between the mean scores of pre-attitude score and post- attitude score of the control and experimental groups.

\section{Introduction}

There is an ongoing effort in education today among teachers specifically in curriculum development to improve methods of instruction to promote the development of higher academic skills in students. This has led to the development of instructional methods that seek to have the students engaged in the active pursuit of knowledge rather than have the information presented to them orally or through demonstrations by the teacher. Pursuit of knowledge should bear some of the critical features of scientific investigation such as identification of research problems, hypothesis formation, and the collection and interpretation of data. In general, along with. Teaching preparation for public school teachers in science is also a factor in learning. There is only a small fraction of teachers in senior high school that qualified and capable to Biology. Although these numbers have increased for public schools due to scholarship efforts of the DOST-SEI, there is still a need to have programs for them.

The standard of education provided to students by teachers is highly dependent on what teachers do in the classroom. Thus, biology teachers need to ensure that their teaching is productive in preparing the students of today to become good citizens of tomorrow. Teachers should have the knowledge of how students learn biology and how best to teach. Changing the way, we teach and what we teach in science is a continuing professional concern. Efforts should be taken now to direct the presentation of science lessons away from the traditional methods to a more student-centered approach. The science curriculum for senior high school in the Philippines has been designed as to provide students with the knowledge and skills in science, develop thinking skills and strategies to enable them to solve problems and make decisions in everyday life (Montebon, 2014).

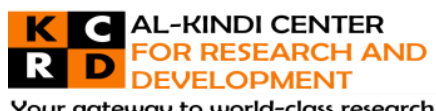

Your gateway to world-class research

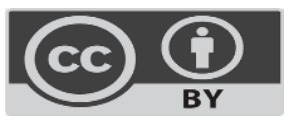

Published by Al-Kindi Center for Research and Development. Copyright (c) the author(s). This open access article is distributed under a Creative Commons Attribution (CC-BY) 4.0 license 
In Graceville National High School reveals in the previous mean percentage score in biology in the School Year 2019-2020, are below $50 \%$. The issue of underachievement has been a source of worry to parents, curriculum chairperson and science subject group head, and science teachers. Moreover, based on the classroom observation in biology class have shown that several factors militate against improved and effective academic achievement of students in biology and other science subjects. These include the application of wrong and ineffective instructional strategies in schools. These seem not to help students acquire science process skills that will enable them to understand scientific concepts to excel in examinations, thereby limiting their ability to live self-reliant lives in the society after graduation from senior high school.

Consequently, teachers need to be exposed to effective teaching and learning methods that are learner-centered rather than teacher-centered to tackle the problem of teacher-centered teaching and the low achievement and negative attitude towards biology. To effectively master the subject matter, the learner-centered teaching and learning methods actively involve the learner in the learning process and foster a positive attitude towards the subject. The teaching strategies adopted by a teacher should make learning more learner-centered to promote imaginative, critical, and creative skills in learners, resulting in better achievement of educational goals to improve academic achievement. Therefore, the study sought to determine the effectiveness of cooperative learning approach against conventional teaching on the students' academic achievement and their attitude towards teaching biology.

\subsection{Research Questions}

This study was undertaken to compares the application of Cooperative learning approach against Direct Instruction Approach among the Grade 11 Senior High School Students.

Specifically, the research tried to answer the following questions:

1. Is there a significant difference in the academic achievement of the students in Biology who were exposed to cooperative learning approaches from those in Direct Instruction Approaches as measured by a researcher- made achievement - test as describes in the following?
a) Pre - achievement scores
b) Post - achievement scores
c) Gain Scores

2. Is there a significant difference in the attitude of students towards biology after being exposed to cooperative learning approaches and those student in Biology who were taught using the Direct Instruction Approaches?
a) Pre - attitude scores
b) Post - attitude scores
c) Gain Score

\section{Literature Review}

Various researches have studied was reported on effects of cooperative learning on student's achievements and attitude. This may be because of the changing condition of education set - up of the students. Different factors that negatively affect the learning process of the students gave rise for methods and strategies that will help the students.

\section{Student's Achievements}

Annowar and Tarmizi (2013) conducted a study to identify the effects of cooperative learning on students' mathematics achievement and attitudes towards mathematics in selected secondary schools in Bangladesh. A total of 80 students (40 from Boys' school and the other 40 from Girls' school) of grade nine participated in this study where quasi-experimental design was administered. Data were analyzed using independent-sample test. The results showed that cooperative learning had significant effects on mathematics achievement and attitudes towards mathematics. It was found that students' performance in mathematics was affected by exposure to the cooperative learning. The findings of this study have shown a great improvement in mathematics achievement mathematics. Therefore, cooperative learning can be successfully used to promote student' performance in mathematics in secondary schools in Bangladesh.

Tran (2014) conducted an experimental study to investigated the effects of cooperative learning on the achievement and knowledge retention of 110 first-year primary education students toward the psychology subject over the eight weeks of instruction at an Giang University. These tertiary students were divided into two matched groups of 55 to be taught by the same lecturer. In the experimental group, cooperative learning was employed, while in the control group, lecture-based teaching was used. The results showed that after approximately 8 weeks students who were instructed using cooperative learning achieved significantly higher scores on the achievement and knowledge retention posttests than did students who were instructed using lecture-based teaching. The study supports the effectiveness of cooperative learning in Vietnamese higher education. 
Nnorom (2015) examined the effect of cooperative learning instructional strategy on senior secondary school students' achievement in biology in Anambra State, Nigeria. The research design employed in this study was the quasi-experimental; specifically, pretest, post test, non equivalent control group design. A sample of one hundred and eleven (111) Senior Secondary one (SS1) students drawn from two coeducational secondary schools in Nnewi Education zone of Anambra State, Nigeria. Two research questions and two null hypotheses guided the study. An instrument known as Test (BAT) with a reliability coefficient of 0.79 was adopted and duly validated by experts. Mean and standard deviation was used to answer the research questions, while the Analysis of Covariance (ANCOVA) was used to test the hypotheses at 0.05 level of significant. The results revealed that students taught using cooperative learning instructional strategy perform better in Biology Achievement Test than those taught using lecture method of instruction. There was no interaction between methods and gender on students Biology Achievement Test. Based on the result obtained, it was therefore recommended that teachers should be encouraged to use cooperative instructional strategy to teach biology and other sciences, technology, engineering and mathematics subjects in secondary schools.

Ajaja (2010), determine how the adoption of cooperative learning as an instructional strategy for teaching Integrated Science influences students' achievement and attitude towards studies. The study also determined how moderating variables like sex and ability affect students' achievement in Integrated Science when cooperative learning is used as an instructional strategy. To guide this study, five hypotheses were stated and tested at 0.05 level of significance. The design of the study was a $2 \times 2 \times 2 \times 2$ factorial, pre-test, post-test control group design. These included two instructional groups (cooperative and traditional classroom groups), sex (male and female), ability (high and low), and repeated testing (pre-test and post-test). The population of study was made up of 205 JS III students from where a sample of 120 students was randomly selected. The instruments used for the collection of data included: a Scholastic Ability Test in Integrated Science (SATIS), Students' Attitude Scale (SAS) and Integrated Science Achievement Test (ISAT). All the data collected were analyzed with analysis of co-variance statistic. The major findings of the study included: a significant higher achievement test scores of students in cooperative learning group than those in traditional classroom; a significant higher attitude scores of students in cooperative learning group than those in traditional classroom; a significant higher achievement test scores of all students of varying abilities in cooperative learning group than those in traditional classroom; a nonsignificant difference in achievement test scores between the male and female students in the cooperative learning group, and no significant interaction effect between sex and ability, sex and method, ability and method and among method, sex and ability on achievement.

Altun and Eravwoke (2015) conducted a study to investigate the efficiency of learning plan implementation prepared with the cooperative learning method. In particular, the study addresses the effect of cooperative learning on students' achievement and their views regarding the 'Systems in Our Body' unit of the 6th grade Science and Technology lesson. For this purpose, mixed method was used. The study is conducted in the second term of the 2013-2014 academic year, on a study group consisted of 7 girls and 13 boys, a total of 20 students of a private middle school in Istanbul. An achievement scale was utilized for the quantitative data and focus group interviews were hold for the qualitative data. While t-test was used for the quantitative findings, content analysis technique was used for the qualitative data. The result of the study indicated that $C L$ method had a favorable effect on learning. The cooperation-based learning-teaching environment provided cooperation, supported permanent learning, provided opportunities to be successful, contributed to the development of social and personal skills, but also caused worry as it requires students to be successful at all stages.

Sani (2015) investigated the effects of cooperative learning as an instructional strategy for teaching Quantitative Chemistry. The study also investigated how other variables like sex affect students' performance in quantitative chemistry when cooperative learning was used as an instructional strategy. To guide this study, three hypotheses were formulated and tested at 0.05 level of significance. The study employed a pre-test- post-test quasi-experimental design. This means that a pre-test post-test was given to both control and experimental groups. The population of study was made up of 980 SS II chemistry students in Kebbi state, from where a sample of 200 students was purposively selected. The instruments used for the collection of data were Cooperative learning guide (CLG) and Achievement test in quantitative chemistry (ATQC). All the data collected were analyzed using t- test statistics. The major findings of the study were: the students in cooperative learning group performed higher than those in traditional classroom learning group; there is also an insignificant difference in performance between the male and female students in the cooperative learning group. Based on the findings, it was recommended that cooperative learning strategy should be adopted by all secondary school chemistry teachers as an effective learning strategy in order to improve students' performance.

Bukunola and Idowu (2012), conducted a study to investigate the effectiveness of cooperative learning strategies on Nigerian Junior Secondary students' academic achievement in basic science. Quasi experimental pretest - posttest - delayed posttest control group design was used by the researchers to carry out the study. The study was happened from CSIT department, faculty of education, Olabisi Onabanjo University, Ago-Iwoye and Basic science department, school of science, tai Solarin College of 
Education, Omu-ljebu, South-west, Nigeria, between March 2009 and October 2010. The treatments were at two levels: cooperative learning strategies (learning together and jigsaw II) and conventional lecture method, which was the control group. The moderating variable was anxiety (high and low). Total number of one hundred and twenty students (120) obtained from the intact classes of the three selected Junior Secondary Schools in South-west Nigeria participated in the study. Achievement Test for Basic Science Students (ATBSS), and Basic Science Anxiety Scale (BSAS) were the main instruments used to collect data from students. Descriptive statistics and Analysis of Covariance (ANCOVA) were used to analyze the data collected. Also, Multiple Classification Analysis (MCA) was used to determine the magnitude of the mean achievement scores of students exposed to the different treatment conditions. The results of this study indicated that there were significant main effects of treatment on all the dependent measures. There were also significant main effects of anxiety on the students' post and delayed-post academic achievement scores in basic science. Furthermore, there were significant interaction effects of treatment and anxiety on the academic achievement of students at the posttest and delayed-posttest levels. Conclusion: This study revealed that students in the two cooperative learning strategy (Learning Together and Jigsaw II) groups had higher immediate and delayed academic achievement mean scores than the students in the conventional-lecture group. Learning together and Jigsaw II cooperative teaching strategies were found to be more effective in enhancing students' academic achievement and retention in basic science more than the conventional-lecture. When friendliness is established, students are motivated to learn and are more confident to ask questions from one another for better understanding of the tasks being learned.

Muraya and Kimamo (2011), conducted a study sought to determine the effect of cooperative learning approach on mean achievement scores in Biology of secondary school students. Solomon-four non-equivalent-control-group design was used, and the target population comprised 183 form two students in four secondary schools. Students were taught one Biology topic for five weeks and cooperative learning approach was used in experimental groups while the regular teaching method was used in control groups. Pre-test was administered before treatment and a post-test after treatment. A Biology Achievement Test was used to measure students' achievement and it attained a reliability coefficient of $0.84(\mathrm{~N}=59)$ at pilot testing. Data was analyzed using t-tests, ANOVA and ANCOVA and hypotheses were accepted or rejected at significant level of $P \leq 0.05$. Cooperative learning approach resulted in significantly higher mean achievement scores compared to regular teaching method and gender had no significant influence on achievement. It was concluded that cooperative learning approach is an effective teaching approach which Biology teachers should be encouraged to use.

\section{Student Attitudes}

Mehta and Kulshrestha (2015), conducted a study about to find out the set forth ideas on how to implement cooperative learning and examine its effect on social and cooperative skills while imparting science education at the Secondary Level. The strategy used is Jigsaw Technique making heterogeneous groups based on intelligence and gender. Instructional material and observation schedule were constructed by researchers. The cooperative skills of the students were found improving during the experimental period, and they developed positive interdependence, face-to-face interaction skills, and feeling of individual accountability, as compared by Mann Whitney $U$ test. The students developed the feeling of working in a group in the classroom of science, and it also improved performance, as the discussion always leads to a considerable degree of clarity of concepts.

Farzaneh and Nejadansari (2014), conducted for investigating the efficiency of different models of reading instruction. The aim of this paper was to investigate students' attitude towards using cooperative language learning techniques for reading instruction. Although cooperative methods are becoming more prevalent in private language schools, there are few studies regarding evaluating the students' attitude towards using cooperative learning for instructing reading comprehension in Iranian context. Evaluation of students' attitude towards the cooperative language learning in this research project was conducted using a survey questionnaire. Analysis of the quantitative questionnaire results showed that the participants generally tend towards supporting the implementation of cooperative strategies in teaching and learning reading comprehension.

Akhtar, et al (2015), examined the views about cooperative learning in domain of group projects of graduating students of the Departments of Statistics and Economics of Arid Agriculture University Rawalpindi. A semi-standardized instrument measuring the attitudes on a three-point Likert scale was adopted for data collection. Analysis of the data yielded that student was favorable to do work on group projects along with associated cooperative learning methods. The results of this study suggest that students could be developing different attitudes toward teamwork from their educational experiences. The challenge for University educators is to develop skills to facilitate positive teamwork experience among their students who will need to interact with each other's in transnational teams in the workplace of the future.

\section{Methodology}

This study employed the experimental type of research. This type of research seeks to determine the effect of one or more manipulative factors upon a dependent variable under controlled condition on a carefully controlled sample. The design 
compares the result obtained from an experimental sample with the control sample which is practically identical to the experimental sample except for the one aspect whose effect is being tested. It also provides a blueprint for the procedure that helps the researcher to test his hypothesis by arriving at relevant conclusions about the relationships between independent and dependent variables and the conceptual framework under which the experiment is carried out.

$$
\begin{array}{llll}
\mathrm{R} & \mathrm{O}_{1} & \mathrm{X} & \mathrm{O}_{2} \\
\mathrm{R} & \mathrm{O}_{3} & X & \mathrm{O}_{4}
\end{array}
$$

Where:

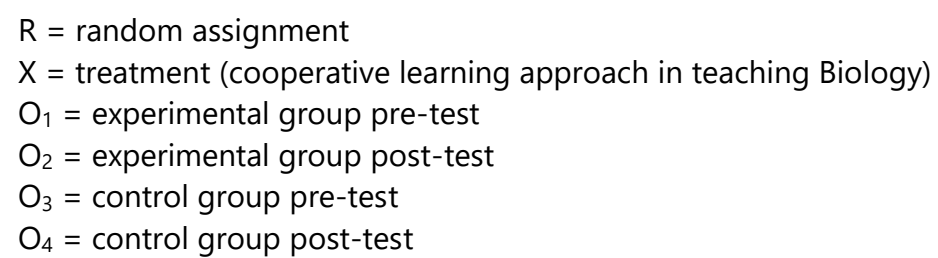

The design above involved two groups randomly allocated. These groups were pre - tested and post - tested but only the experimental group was given the treatment. The main independent variable was the method of instruction classified as the direct instruction and cooperative approach. The effect of the independent variable was measured on the following dependent variables: achievement test scores in Biology, attitude towards the subject.

\subsection{Respondents}

The respondents of the experiment were 30 students from the two intact section of Grade 11 student from the Graceville National High School., a Public School in Division of City of San Jose del Monte Bulacan. The ratio of males to females among the participants depends on the number of enrollees this A.Y. 2019-2020.

\subsection{Sampling Methods}

The students were chosen according to their strand Technical, Vocational Livelihood strand (Home Economics) and Technical, Vocational Livelihood strand (Information, Communication, and Technology). Two sections were selected to be the participants of the experiment based on their previous grades in earth and life science.

Table 1: Frequency and Percentage of the Respondents during the Research Study.

\begin{tabular}{|c|c|c|}
\hline Group & Frequency & Percentage \\
\hline Control Group (TVL: ICT) & 15 & $50 \%$ \\
\hline Experimental Group (TVL: HE) & 15 & $50 \%$ \\
\hline TOTAL & 30 & $100 \%$ \\
\hline
\end{tabular}

\subsection{Instruments}

\section{Researcher- Made -Achievements Tests.}

Both groups were pre - and post - tested with the use of the researcher- made- test developed by the researcher and validated by the rosters of experts. The Test is called Standard - Based Achievement Test in Biology. It is a test that measures student's achievement and competencies in Biology based on the Enhance Basic Education Curriculum K to 12 curriculums for Core Subject and on the national and international norm includes the topics of themes in biology, bioenergetics, perpetuation of life, how animals and plants survive, the process of evolution and interaction and interdependence. The researcher- made achievement test in Biology also includes:

1. Pinpointing the areas and strength of curriculum and instruction.

2. Determining proficiency levels of students

3. Determining performance of students against the school, national and international norms.

The raw score from the items answered correctly is transformed into what is termed as Scaled Ability Score (SAS). The scores are grouped into four proficient levels as shown in Table 2.

Table 2: Scaled Ability Score (SAS).

\begin{tabular}{|c|c|}
\hline Scaled Ability Score & Qualitative descriptions \\
\hline $38-50$ & Excellent / high proficient \\
\hline $25-37$ & Meets standards/ proficiency \\
\hline $13-24$ & Progressing towards standards \\
\hline $0-12$ & Does not meet the standards \\
\hline
\end{tabular}




\section{Attitudes Survey Scale}

Student's attitude towards the subject was measured using the adapted version of the National Biomedical Research Institute of Texas University (http://people.cehd.tamu.edu/ /burlbaw/nsbri/scienceattitudesurvey.html retrieved Sept. 2000). Table 3: shows how respondents' scores are grouped into 4 descriptive categories.

\begin{tabular}{|c|c|}
\hline Scaled Score & Qualitative descriptions \\
\hline $75-90$ & highly positive \\
\hline $62-74$ & Moderately positive \\
\hline $47-61$ & moderately negative \\
\hline 46 and below & negative \\
\hline
\end{tabular}

It is an 18 - items Likert scale that measures the attitude of students toward the subject of biology and towards learning the subjects. Students are asked to assess 18 statements on a scale of 1-5 and total scores range from the lowest score of 18 to the maximum score of 90 . The attitude Survey covered student's perception on three constructs: usefulness of science as a subject, feelings towards work in the science classroom and taking responsibility in discovering for himself concepts in Biology. Items $6,7,10,11,16$ were phrases in the negative and thus the scored in reverse with a score of 1 corresponding to the lower end of scale and score of 5 corresponding to the end of the scale.

\subsection{Data Collection Procedure}

Prior to the beginning of the academic year, two intact Grade 11 classes were part of this study. The researcher selected for the study before these classes were scheduled. One class was randomly chosen to receive direct instruction approach and acted as the control group, and the other received Cooperative learning approach and acted as the treatment group in Biology subject for 8 weeks. A pretest on Biology knowledge was administered to both groups before the treatment.

The Biology part of Earth and Life Science is in the 2nd Quarter with 40 hours allotted for this quarter. The same biology taught both groups. In the control group, the lecturer instructed students to learn the Biology knowledge content because of direct instruction in logical steps, and students worked as a whole class group. In the treatment group, the lecturer guided students to learn the Biology knowledge content using the Cooperative learning approach In this group, the teacher applied the following eight steps (1) the teacher organized the learning materials and identified the objectives of the subject matter, (2) the teacher introduced the structure of the lesson, and raised the outcomes expected, (3) the teacher formed groups, (4) the teacher lecturer moved students to groups assigned, (5) the teacher delivered the learning materials to students, (6) students studied their learning materials, (7) students helped each other to learn their learning materials, (8) students presented their understanding of the entire unit, and (9) the teacher lecturer assessed students' understanding through their presentation in front of the whole class. This whole process was repeated 8 times, once for each unit of work. Throughout the experiment both groups could not meet at the same time as they were taught by the same Biology teacher. Therefore, the treatment group was conducted on Wednesdays, while the control group was on Fridays. Both groups covered the same biology knowledge content and received biology instruction for the same amount of time in the mornings, and in the same room. All students in both groups participated in one instructional session of 240 minutes per week for each unit over the 8 weeks. After the treatment, both groups took a posttest measuring students' achievement in the tenth week and an attitude test measuring students' knowledge attitude test toward Biology as subject.

\section{Data Analysis}

\section{A. Pre experimental data}

The following statistical tool were used to determine the entry level of student and to determine they were comparable in terms of achievement in biology, and in their attitudes towards learning in Biology.

Mean. This was used to determine the average performance of each group in the achievement test and attitude test.

$\mathrm{T}$ - Test for independent means. To determine whether there are significant differences in the achievement the $t$ test for independent was utilized.

$\mathrm{F}$ - Test. This is used to compare the pre - post experiment attitude of the groups and to determine if there was no significant difference exists between the two groups.

\section{B. Post Experimental data}

T - Test for dependent means. This statistical measure is used to determine the significant gains made between the pretest and post test score of two groups. The test, likewise, used the 0.05 level of significance.

$\mathrm{T}$ - Test for independent means. This is used to determine whether the two groups posted significant difference in their achievement in terms of their achievement scores after the experiment. 


\section{Results and Discussion}

The data collected in this study were comprehensively, analyzed and interpreted to established clarity and consistency.

Table 3: Pre - Achievement Scores of the two Groups

\begin{tabular}{|c|c|c|c|c|}
\hline Group & $\begin{array}{c}\text { Mean } \\
\text { Score }\end{array}$ & $\begin{array}{c}\text { Standard } \\
\text { Deviation }\end{array}$ & Verbal Interpretation & Mean Difference \\
\hline Control Group & 13 & 2.67 & $\begin{array}{c}\text { Progressing towards } \\
\text { standards }\end{array}$ & $\mathbf{2} 2.26$ \\
\hline Experimental Group & 15.26 & 2.93 & $\begin{array}{c}\text { Progressing towards } \\
\text { standards }\end{array}$ & \\
\hline
\end{tabular}

The mean and standard deviation of each group was calculated based on the scores of pre- achievement test. The controlled group got the mean of 13 which is lower than the mean score of the experimental group which is 15.26 with a mean difference of 2.26. On the other hand, the standard deviation of the experimental group (Cooperative Learning Approach) is 2.93 greater, making the scores more distrusted compared to the standard deviation of the control group (Conventional Approach ) which is 2.67. Thus, the results of pre- achievement score show that the respondents in the control and experimental group have almost same level of pre- achievement score as reflected in Progressing towards standards.

Table 4: Comparison of Pre -Achievement Scores of the Two groups

\begin{tabular}{|c|c|c|c|c|c|}
\hline df & t- test computed & t- test critical value & Probability Level & Decision & $\begin{array}{c}\text { Verbal } \\
\text { Interpretation }\end{array}$ \\
\hline 14 & 2.003 & 2.1448 & $\mathrm{P}>0.05$ & Accept the $\mathrm{H}_{\circ}$ & Not significant \\
\hline
\end{tabular}

Based on tabulated data below, the degree of freedom of 14 and t-test computed value of 2.003 against the t-test critical value of 2.1448 with probability level greater than 0.05 . This indicates that there is failure to reject the null hypothesis. Therefore, there is no significant difference between the pre - achievement score of the two groups.

Table 5: Post - Achievement Scores of the two Groups

\begin{tabular}{|c|c|c|c|c|}
\hline Group & Mean Score & $\begin{array}{c}\text { Standard } \\
\text { Deviation }\end{array}$ & Verbal Interpretation & $\begin{array}{c}\text { Mean } \\
\text { Difference }\end{array}$ \\
\hline Control Group & 36.73 & 2.89 & Meets standards/ proficiency & 5.76 \\
\hline Experimental Group & 42.13 & 3.70 & Excellent / high proficient & \\
\hline
\end{tabular}

The tabulated data shows the mean score in the Post - achievement test and the standard deviation of the control group and experimental group. The mean of the experimental group is 42.13 is greater compared to the mean of the controlled group, 36.73. furthermore, the standard deviation of the experimental group is higher than the controlled group which mean that the scores of the experimental group is well distributed than the controlled group.

Table 6: Comparison of Post -Achievement Scores of the Two groups

\begin{tabular}{|c|c|c|c|c|c|}
\hline df & t- test computed & t- test critical value & Probability Level & Decision & $\begin{array}{c}\text { Verbal } \\
\text { Interpretation }\end{array}$ \\
\hline 14 & 4.9731 & 2.1448 & $\mathrm{P}<0.05$ & Reject the $\mathrm{H}_{\circ}$ & Highly significant \\
\hline
\end{tabular}

Based on tabulated data below, the degree of freedom of 14 and t-test computed value of 4.9731 against the t-test critical value of 2.1448 with probability level was less than 0.05 . Consequently, the null hypothesis must be rejected. Thus, there is a great difference between the post - achievement score of the two groups.

Table 7: Comparison of Pre- Achievement Scores and Post -Achievement Scores of the Control Group

\begin{tabular}{|c|c|c|c|c|c|c|c|c|}
\hline & Mean & SD & df & $\begin{array}{c}\text { t- test } \\
\text { computed }\end{array}$ & $\begin{array}{c}\text { t- test } \\
\text { critical } \\
\text { value }\end{array}$ & $\begin{array}{c}\text { Probability } \\
\text { Level }\end{array}$ & Decision & Verbal \\
\hline $\begin{array}{c}\text { Pnterpretation } \\
\text { Achievement } \\
\text { Scores }\end{array}$ & 13 & 2.67 & & & & & Reject the & Highly significant \\
\hline
\end{tabular}




\begin{tabular}{|c|l|l|l|l|l|l|l|l|}
\hline $\begin{array}{c}\text { Post - } \\
\begin{array}{c}\text { Achievement } \\
\text { Scores }\end{array}\end{array}$ & 36.73 & 2.89 & & & & & $H_{0}$ & \\
\hline
\end{tabular}

Based on the tabulated data above, with the degree freedom of 14 and the computed $t$ - test is 31.0194 against the $t$-test critical value of 2.1448 with the probability level of less than 0.05 , this indicates that there is a need to reject the null hypothesis. Therefore, there is a significant difference between the pre - achievement score and post - achievement score of the control group.

Table 8: Comparison of Pre- Achievement Scores and Post -Achievement Scores of the Experimental group

\begin{tabular}{|c|c|c|c|c|c|c|c|c|}
\hline & Mean & SD & df & $\begin{array}{c}\text { t- test } \\
\text { computed } \\
\text { critical } \\
\text { value }\end{array}$ & $\begin{array}{c}\text { Probability } \\
\text { Level }\end{array}$ & Decision & $\begin{array}{c}\text { Verbal } \\
\text { Interpretation }\end{array}$ \\
\hline $\begin{array}{c}\text { Pre- } \\
\text { Achievement } \\
\text { Scores }\end{array}$ & 15.26 & 2.93 & & & & & & \\
\hline $\begin{array}{c}\text { Post- } \\
\text { Achievement } \\
\text { Scores }\end{array}$ & 42.13 & 3.70 & 14 & 19.6711 & 2.1448 & $\begin{array}{r}\text { Reject the } \\
H_{0}\end{array}$ \\
\hline
\end{tabular}

Based on the tabulated data above, the degree freedom of 14 and the computed $t$ - test is 19.6711 against the t-test critical value of 2.1448 with the probability level is less than 0.05 . Consequently, the null hypothesis must be rejected. Therefore, there is a significant difference between the pre - achievement score and post - achievement score of the experimental group.

Table 9: Gain Score of the Two Groups in Achievement Test

\begin{tabular}{|c|c|c|c|c|c|c|}
\hline \multirow[b]{2}{*}{ Groups } & \multirow[b]{2}{*}{ Number } & \multicolumn{2}{|c|}{ Mean } & \multicolumn{2}{|c|}{ Standard deviation } & \multirow[b]{2}{*}{$\begin{array}{c}\text { Gained } \\
\text { Score } \\
(\%)\end{array}$} \\
\hline & & $\begin{array}{c}\text { Pre- } \\
\text { achievement } \\
\text { Score }\end{array}$ & $\begin{array}{c}\text { Post - } \\
\text { achievement } \\
\text { Score }\end{array}$ & $\begin{array}{c}\text { Pre- } \\
\text { achievement } \\
\text { Score }\end{array}$ & $\begin{array}{c}\text { Post - } \\
\text { achievement } \\
\text { Score }\end{array}$ & \\
\hline Control & 15 & 13 & 36.73 & 2.67 & 2.89 & 36.49 \\
\hline Experimental & 15 & 15.26 & 42.13 & 2.93 & 3.70 & 41.86 \\
\hline
\end{tabular}

Table 9 shows the gained scores of the controlled and experimental groups. It shows that the experimental group gained 41.86 percent from the pre- and post-achievement test greater than the controlled group gained 36.49 percent.

Table 10: Pre - Attitude Scores of the two Groups

\begin{tabular}{|c|c|c|c|c|}
\hline Group & $\begin{array}{c}\text { Mean } \\
\text { Score }\end{array}$ & $\begin{array}{c}\text { Standard } \\
\text { Deviation }\end{array}$ & Verbal Interpretation & Mean Difference \\
\hline Control & 77.33 & 11 & Highly positive & \\
\cline { 1 - 3 } Experimental & 79.33 & 6.26 & Highly positive & 2 \\
\hline
\end{tabular}

The abovementioned tabulated data shows the Pre- attitudes of two groups. The mean attitudes scores of the experimental group is 79.33 greater than the mean attitude scores of the control group which is 77.33 . In addition, the mean score of pre -attitude survey of two groups have mean difference of 2. Furthermore, the Standard deviation of experimental group is 6.26 destructed than the control group which is 11 . Thus, the results of pre- attitude score show that the respondents in the control and experimental group have almost same level of pre- attitude score as reflected in Highly positive. 
Table 11: Post - Attitude Scores of the two Groups

\begin{tabular}{|c|c|c|c|c|}
\hline Group & $\begin{array}{c}\text { Mean } \\
\text { Score }\end{array}$ & $\begin{array}{c}\text { Standard } \\
\text { Deviation }\end{array}$ & Verbal Interpretation & Mean Difference \\
\hline Control Group & 81.73 & 5.13 & Highly positive & .20 \\
\hline Experimental Group & 81.93 & 5.75 & Highly positive & \\
\hline
\end{tabular}

The abovementioned tabulated data shows the Post- attitudes of two groups. The mean attitudes scores of the experimental group is 81.93 greater than the mean attitude scores of the control group which is 81.73 . In addition, the mean score of posattitude survey of two groups have mean difference of .20. Furthermore, the Standard deviation of experimental group is 5.75 greater than the control group which is 5.13. Thus, the results of post- achievement score show that the respondents in the control and experimental group have almost same level of post- attitude score as reflected in Highly positive.

Table 12: Gain Score of the Two Groups in Attitude Survey

\begin{tabular}{|c|c|c|c|c|c|c|}
\hline \multirow{2}{*}{ Groups } & \multirow{2}{*}{ Number } & $\begin{array}{c}\text { Pre- attitude } \\
\text { Score }\end{array}$ & $\begin{array}{c}\text { Post - attitude } \\
\text { Score }\end{array}$ & $\begin{array}{c}\text { Pre- attitude } \\
\text { Score }\end{array}$ & $\begin{array}{c}\text { Post - attitude } \\
\text { Score }\end{array}$ & $\begin{array}{c}\text { Gained } \\
\text { Score (\%) }\end{array}$ \\
\cline { 3 - 6 } & 15 & 77.33 & 81.73 & 11 & 5.13 \\
\hline $\begin{array}{c}\text { Experimental } \\
\text { Group }\end{array}$ & 15 & 79.33 & 81.93 & 6.26 & 5.75 \\
\hline
\end{tabular}

Table 11 shows the gained scores of the controlled and experimental groups in attitude survey. It shows that the experimental group gained 81.90 percent from the pre- and post-attitude survey greater than the control group gained 81.69 percent.

Table 13: Comparison of Attitudes Scores of the Control Group

\begin{tabular}{|c|c|c|c|c|c|c|c|c|}
\hline & Mean & SD & df & $\begin{array}{c}\text { F- test } \\
\text { computed }\end{array}$ & $\begin{array}{c}\text { F- test } \\
\text { critical } \\
\text { value }\end{array}$ & $\begin{array}{c}\text { Probability } \\
\text { Level }\end{array}$ & $\begin{array}{c}\text { Decision } \\
\text { Interpretation }\end{array}$ \\
\hline $\begin{array}{c}\text { Pre- attitude } \\
\text { Scores }\end{array}$ & 77.33 & 11 & \multirow{2}{*}{13} & 0.31 & 0.38 & $\mathrm{P}>0.05$ & $\begin{array}{c}\text { Accept the } \\
\mathrm{H}_{0}\end{array}$ & $\begin{array}{c}\text { Not } \\
\text { significant }\end{array}$ \\
\hline $\begin{array}{c}\text { Post -attitude } \\
\text { Scores }\end{array}$ & 81.73 & 5.13 & & & & \\
\hline
\end{tabular}

The computed value of $\mathrm{F}$ - test is 0.31 is less than the critical value of 0.38 ; therefore, the null hypothesis cab ne accepted. Thus, there is no a significant difference between the mean scores of pre-attitude score and post- attitude score of the controlled group.

Table 13: Comparison of Attitudes Scores of the Experimental Group

\begin{tabular}{|c|c|c|c|c|c|c|c|c|}
\hline & Mean & SD & df & $\begin{array}{c}\text { F- test } \\
\text { computed }\end{array}$ & $\begin{array}{c}\text { F- test } \\
\text { critical } \\
\text { value }\end{array}$ & $\begin{array}{c}\text { Probability } \\
\text { Level }\end{array}$ & $\begin{array}{c}\text { Decision } \\
\text { Interpretation }\end{array}$ \\
\hline $\begin{array}{c}\text { Pre- attitude } \\
\text { Scores }\end{array}$ & 79.33 & 6.26 & \multirow{2}{*}{13} & 0.03 & 2.58 & $\mathrm{P}>0.05$ & $\begin{array}{c}\text { Accept the } \\
\mathrm{H}_{0}\end{array}$ \\
\hline $\begin{array}{c}\text { Post -attitude } \\
\text { Scores }\end{array}$ & 81.73 & 5.13 & & & & Not significant \\
\hline
\end{tabular}


The computed value of F- test is 0.03 is less than the critical value of 2.58 ; therefore, the null hypothesis cab ne accepted. Thus, there is no significant difference between the mean scores of pre-attitude score and post- attitude score of the experimental group.

\section{Conclusion}

In the light of the findings of the study, the following conclusions were drawn:

1. The results show that the control group got the mean lower than the mean score of the experimental group in the pre-achievement test.

2. Comparing the mean scores of the two groups in pre- achievement test reveals that there is a failure to reject the null hypothesis. Therefore, there is no significant difference between the pre - achievement score of the two groups.

3. The mean of the experimental group is greater compared to the mean of the control group in post -achievement test.

4. The t-test results show there is a significant difference between the pre - achievement score and post - achievement score of the control group.

5. The results show that there is a significant difference between the pre - achievement score and post - achievement score of the experimental group.

6. The results show that the gained score from the pre- and post-achievement of the experimental group is greater than the control group's gained score.

7. The mean pre- attitudes scores of the experimental group are greater than the mean attitude scores of the controlled group.

8. The mean post - attitudes scores of the experimental group are greater than the mean attitude scores of the control group.

9. The results show that the experimental group gained scores from the pre- and post-attitude survey are greater than the control group gained score.

10. The F -test reveals that there is no significant difference between the mean scores of pre-attitude score and postattitude score of the control group.

11. The results shows that there is no significant difference between the mean scores of pre-attitude score and postattitude score of the experimental group.

\section{References}

[1] Ajaja, O. P., \& Eravwoke, O. U. (2010). Effects of cooperative learning strategy on junior secondary school students achievement in integrated science. The Electronic Journal for Research in Science \& Mathematics Education, 14(1).

[2] Akhtar, K., Perveen, Q., Kiran, S., Rashid, M., \& Satti, A. K. (2012). A study of student's attitudes towards cooperative learning. International Journal of Humanities and Social Science, 2(11), 141-147.

[3] Hossain, A., \& Tarmizi, R. A. (2013). Effects of cooperative learning on students' achievement and attitudes in secondary mathematics. Procedia-Social and Behavioral Sciences, 93, 473-477.

[4] Bukunola, BA J \& Idowu, O D. (2012). Effectiveness of Cooperative Learning Strategies on Nigerian Junior Secondary Students' Academic Achievement in Basic Science. British Journal of Education, Society \& Behavioural Science, 2(3), 307-325.

[5] Farzaneh, N., \& Nejadansari, D. (2014). Students' Attitude towards Using Cooperative Learning for Teaching Reading Comprehension. Theory \& Practice in Language Studies, 4(2).

[6] Mehta, S \& Kulshrestha, A K. (2014). Implementation of Cooperative Learning in Science: A Developmental-cum-Experimental Study. Education Research International. https://doi.org/10.1155/2014/431542.

[7] Montebon, D. T. (2014). K12 science program in the Philippines: Student perception on its implementation. International Journal of Education and Research, 2(12), 153-164.

[8] Muraya, D. N., \& Kimamo, G. (2011). Effects of cooperative learning approach on biology mean achievement scores of secondary school students in Machakos District, Kenya. Educational Research and Reviews, 6(12), 726-745.

[9] Nnorom, N. R. (2015). Effect of cooperative learning instructional strategy on senior secondary school students achievement in biology in anambra state, Nigeria. International Journal for Cross-Disciplinary Subjects in Education, 5(1), 2424-2427.

[10] Sani, U. T. (2015). Effects of cooperative learning strategy on senior secondary school students' performance in quantitative chemistry in Kebbi state, Nigeria. Journal of Education and Social Sciences, 1, 30-35.

[11] Tran, V. D. (2014). The effects of cooperative learning on the academic achievement and knowledge retention. International journal of higher education, 3(2), 131-140 